\title{
POTATO BY- PRODUCTS AS ANIMAL FEED: \\ 2- MILK YEILD AND MILK COSTITUENTS OF RAHMANY EWES AND GROWTH OF THEIR LAMBS AS AFFECTED BY POTATOES BY-PRODUCTS SOLANINE.
}

Saleh, M.R.M.

Animal Production Research Institute, Agricultural Research Center, Dokki, Egypt.

\begin{abstract}
The present study was carried out to estimate the effect of solanine in potato by-products (PB-P) as a natural toxic component, on milk yeild and its constituents as well as the solanine residue in milk on born lambs of lactating ewes fed on potato by product as silage (PB-PS) or hay (PB-PH). Eighteen lactating Rahmany ewes with an average body weight of $45.4 \pm 0.64 \mathrm{~kg}$ and aged $2.5-3$ years and their born lambs with an average weight of $3.53 \mathrm{~kg}$ (every ewe with her lamb) were used in this study. Ewes were divided into three similar groups (6 animals each) and assigned randomly to three experimental rations according to the requirement of NRC (I990) as follows: (1) $50 \%$ concentrate feed mixture (CFM) $+50 \%$ berseem hay $(\mathrm{BH})$ as a control, (2) $50 \% \mathrm{CFM}+50 \%$ PB-PS and (3) $50 \% \mathrm{CFM}+50 \% \mathrm{~PB}-\mathrm{PH}$. Whereas born lambs were fed on their mother's milk all the experimental period. The experiment lasted for 16 weeks. Body weight gains were 14.7,13.6 and $10.4(\mathrm{~kg})$ for the control, PB-PS and PB-PH, respectively. Solanine values of PB-PS and PB-PH were 8.19 and $24.86 \mathrm{mg} / 100 \mathrm{~g}$, respectively. The digestion coefficients of OM and CF significantly $(\mathrm{P}<0.05)$ increased in $\mathrm{PB}-\mathrm{PH}$ followed by PB-PS than the control. On the other hand, PB-PH showed lower TDN and DCP values than the other tested diets. Milk yield and its constituents were lower in PB-PH compared with the other tested groups, but the ME (Mcal/kg) was higher in PB-PH than PB-PS and the con trol. Milk yield and composition was lower in PB-PH compared with other test groups. Values of white blood cells count, hematocrit, globulin, AST, ALT, urea, creatinine and bilirubin of $\mathrm{PB}-\mathrm{PH}$ group were significantly $(\mathrm{P}<0.05)$ higher than the other tested groups. The water consumption of PB-PH group was higher than PB-PS and control groups, also feed costs of PB-PH and PB-PS were lower than the control group.The $\mathrm{PB}-\mathrm{PS}$ and $\mathrm{PB}-\mathrm{PH}$ in lactiting ewes caused decrease in feed cost and the values were 28.37 and $33.02 \%$ for the PB-PS and PB-PH, respectively than the control. In conclusion, potato by-products as silage could be used safety, successfully and economically in ration of lactating ewes at $50 \%$ of nutritional requirements.

Keywords: Solanine residue, Milk production, Milk constituents, Performance of born lambs.
\end{abstract}

\section{INTRODUTION}

The population of ruminant animals in Egypt was predicated to be as 7.6 million animal units in year 2000.This animals required about 13.2 million tones of TDN and 1.135 million tones of DCP (Abdelhamid et al., 2001). The available conventional feed resources could cover only $84 \%$ and $89 \%$ of the required TDN and DCP, respectively (Abou Akkada, 1984). Shortage of the concentrate feed in Egypt is a well known problem; therefore, several studies were carried out to improve the nutritive values of the poor quality roughages to participate in solution of feed shortage problem and the dramatic increase in prices of animal feed ingredients. There are a few literature on using potato residues in feeding ruminants. Thereby, there is a need for more 
studies on using these by-products in the animals feeding. However, feeding common potato (Solanum tuberosum) led to solanine toxicity and affected performance of starter, growing and finishing pigs (Patil et al., 1972). Jadhav et al. (1981) found natural occurring toxic alkaloids in potatoes by-products. Morris and Lee (1984) and Renwick et al. (1984) reported solanine emberyotoxicity and teratogenicity, as well as inhibition of rat cholinesterase isoenzymes in vitro and in vivo by the potato alkaloid. Alozie et al. (1978) found that the amount of solanine was about $0.01-0.1 \%$ of potatoes dry matter.

This experiment aimed to evaluate the effect of feeding potato by-products in form of silage or hay on milk yield and its constituents, which fed to lactating ewes, and the growth performance of their suckling lambs.

\section{MATERIALS AND METHODS}

This study was carried out at El-Serw Animal Production Research Station, Animal Production Research Institute, Agricultural Research Center, Cairo, Egypt through year 2005.

\section{1- Experimental animals:}

Eighteen Rahmany lactating ewes aged $2.5-3$ years with an average body weight of $45.4 \pm 0.64 \mathrm{~kg}$ with their new born lambs were divided randomly according to their body weight into three equal groups (6 animals each, ewes with their lambs). Each group was housed in an enclosure (pen), all groups were managed under the same conditions. Animals were weighed at the beginning and at biweekly intervals thereafter. The experiment lasted for 16 weeks until weaning.

\section{2- Experimental diets:}

Three experimental diets were given according to NRC (1990), the first group fed $50 \%$ concentrate feed mixture (CFM) $+50 \%$ berseem hay $(\mathrm{BH})$ as a control. The second group fed $50 \%$ CFM $+50 \%$ potato by-products silage (PB-PS). The third group fed $50 \%$ CFM $+50 \%$ potato products hay (PB-PH). The rations were offered twice daily at $8 \mathrm{AM}$ and $3 \mathrm{PM}$. The chemical analysis of the CFM, BH, PB-PS and PB-PH is shown in Table (1). Water was available all times, where the water consumption was daily measured. Samples of feeds were analyzed periodically.

\section{3- Silage making:}

Whole green potato fresh aerial parts in addition to small infirmity and greenish spots tubers from Solanum tuberosum were chopped manually using knives, then wilted by spreading under direct sun for a day thin mixed with wheat straw: potatoes by-product $(4: 1$ ratio $)+5 \%$ molasses $+3 \%$ urea and ensiled in white plastic bags for 2 month before feeding. After ensilage period, the color and odor were examined and samples were taken for chemical analysis, solanine was determined and silage quality test was performed. 
Table (1): Chemical analysis of ingredients and experimental rations fed by Rahmany rams (\% on dry matter basis).

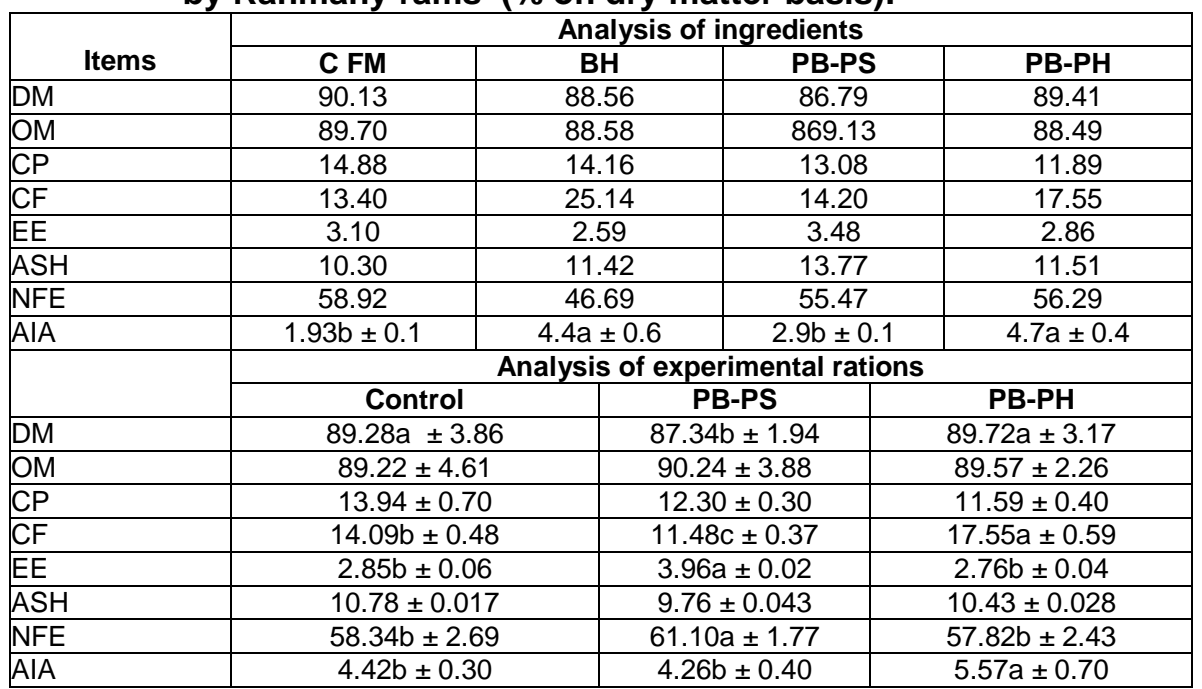

a, b and c means having different superscripts within the same row are significantly different at $\mathrm{P}<0.05$ differ.

\section{3- Silage making:}

Whole green potato fresh aerial parts in addition to small infirmity and greenish spots tubers from Solanum tuberosum were chopped manually using knives, then wilted by spreading under direct sun for a day thin mixed with wheat straw: potatoes by-product $(4: 1$ ratio $)+5 \%$ molasses $+3 \%$ urea and ensiled in white plastic bags for 2 month before feeding. After ensilage period, the color and odor were examined and samples were taken for chemical analysis, solanine was determined and silage quality test was performed.

\section{4- Hay making:}

Also green potato fresh aerial parts and small infirmity and greenish spots tubers from Solanum tuberosum were wilted by spreading under direct sunshine until complete drying, then packed in white bags.

\section{5- Milk yield:}

Young lambs were separated from their mothers for 12 hours, then lambs and ewes were weighed individually, after that lambs were left for suckling their mothers and weighed again, the milk yeild was calculated by difference Milk samples were taken from each ewe and prepared for milk constituents analysis and qualitative determination of solanine.

\section{6- Blood samples:}

Blood samples were collected in heparinzed test tube from each animal before feeding from jugular vein. After measuring the hematological parameters, part of blood samples was immediately centrifuged to separate the plasma at $3000 \mathrm{rpm}$ for 20 minute. Samples were stored frozen immediately at $-20^{\circ} \mathrm{C}$ till analysis. 


\section{Saleh, M.R.M.}

\section{7- Feces collection:}

At the last week of the experiment, feces samples were collected daily for seven successive days from three animals for every tested group for acid insulible ash (AIA) determination. Representatively samples of fresh feces were dried and ground then mixed and kept for chemical analysis and estimation of nutrient digestibility was done using the method of acid insoluble ash (AIA) of Van Keulen and Young (1977).

\section{8- Analytical methods:}

Chemical analysis of feed ingredients and feces was carried out according to A.O.A.C. (2000). Plasma biochemical analysis was done using Biomerieux reagent kits. Solanine was determined according to Carman et al. (1984) and Bushway and Ponnampalam (1985). Milk fat (CF), total protein (TP), total solid (TS), solid not fat (SNF) and ash were determined according to Ling (1963). The $4 \%$ fat corrected milk (FCM) was calculated according to Gaines (1963). Plasma samples were used for determination of total protein (Weichselbaum, 1989), albumin (Doumas et al., 1971), globulin (calculated by difference), urea (Patton and Crouch, 1977), liver enzymes (Reitman and Frankle, 1957), total cholesterol (Monnet, 1963) creatinine (Bartiles, 1971) and bilirubin (Elveback, 1970). Whereas haemoglobin and haematocrit (Linne and Ringsrud, 1992), red and white blood cells (Miller and Weller, 1971) in whole blood.

\section{9- Statistical analysis:}

All numerical data obtained were statistical analyzed by SAS (1996) procedures for personal computer. When F-test was positive, least significant differences (Duncan, 1955) were calculated for the comparisons between treatments.

\section{RESULTS AND DISCUSSION}

\section{1- Solanine residues:}

Solanine residues are determined in both PB-PS and PB-PH, rations as well as milk and faeces (Table 2). The data indicated that solanine significantly increased $(\mathrm{P}<0.05)$ in $\mathrm{PB}-\mathrm{PH}$, milk and faeces of group fed on PB-PH than those fed PB-PS. The data are in agreement with those found by Alozie et al. (1978) who reported inhibition of cholinesterase iso enzymes in vitro and in vivo by the potatoe-solanine. Anon (1984) reported that solanine is a poison associated with a school lunch program. Gull et al. (1970) and Dalvi and Bowie (1983) reported that solanine is a toxic glycoalkaloid in Solanum tuberosum, it deffects the protein digestibility and growth performance. Whereas Hansen (1925) found two fatal cases of potato poisoning. Swinyard and Chaube (1973) and Chabue and Swinyard (1976) reported that solanine is teratogenic and toxicological phenolic compound, from Solanum tuberosum .The data are clearly indicated that the NFE was increased in silage diet whereas CF and ash were decreased than $\mathrm{PB}-\mathrm{PH}$ and control one. 
Table ( 2 ): Solanine levels in potato by -products, milk and faeces (mg).

\begin{tabular}{|c|c|}
\hline \multicolumn{1}{|c|}{ Items } & Solanine (mg) \\
\hline Potato by-products: & $8.19 \pm 0.07$ \\
\hline PB-PS & $24.86 \pm 1.12$ \\
\hline PB-PH & $2.58 \pm 0.01$ \\
\hline MILK from group: & $8.84 \pm 0.26$ \\
\hline PB-PS & $3.37 \pm 0.01$ \\
\hline PB-PH & $6.96 \pm 0.17$ \\
\hline Faeces from group: &
\end{tabular}

\section{2- Silage quality:}

The data in Table (3) clear that the silage of potato by-products showed good quality of the tested parameters in either $\mathrm{pH}$, ammonia, lactic acid and TVFA. Also, NFE was increased in silage whereas crude fiber (CF) and ash were decreased than potatoes hay ration (Table 1). These results are in agreement with those reported by Abou-Akkada and Nour (1986), since ensilage can preserve feed and improve its feeding value.

Table (3): Mean values of different quality parameters of potatoes silage.

\begin{tabular}{|l|c|}
\hline \multicolumn{1}{|c|}{ Items } & PB-PS \\
\hline PH value & $4.69 \pm 0.83$ \\
\hline Ammonia- $\mathrm{N}(\mathrm{mg} / 100 \mathrm{~g})$ & $24.75 \pm 1.57$ \\
\hline Lactic acid(mg/100g ) & $2.31 \pm 0.03$ \\
\hline TVFA( ME q/100g ) & $22.10 \pm 0.70$ \\
\hline Ammonia \% of DM & $7.12 \pm 0.069$ \\
\hline Lactic acid \% of DM & $0.76 \pm 0.004$ \\
\hline
\end{tabular}

\section{3- Feed Intake and water consumption:}

The feed intake values were 2010, 1960 and $2050 \mathrm{~g} / \mathrm{h} / \mathrm{d}$ (on dry matter basis) with no significant differences. Whereas water consumption showed significantly higher $(\mathrm{P}<0.05)$ values with $\mathrm{PB}-\mathrm{PH}$ group than the other treatments, the values were 1875,1710 and $2205 \mathrm{ml} / \mathrm{h} / \mathrm{d}$ for contro, potatoes silage and potatoes hay diets, respectively (Table 4). Water consumption positively correlated with DM intake, CF and ash content (Table 1), solanine content (Table 2), liver and kidney function parameters (Table 7). The results are in agreement with the results obtained in other study (Sultan, 1995). 
Saleh, M.R.M.

Table (4): Feed intake and water consumption of lactating ewe fed on silage or hay (dry matter basis).

\begin{tabular}{|l|c|c|c|}
\hline \multicolumn{1}{|c|}{ Items } & Control & PB-PS & PB-PH \\
\hline No. of animals & 6 & 6 & 6 \\
\hline Body weight (kg) & $45.8 \pm 0.9$ & $44.2 \pm 0.5$ & $45.4 \pm 0.8$ \\
\hline Feed intake (g/h/day) & \multicolumn{3}{|c|}{} \\
\cline { 1 - 2 } CFM & $1173 a \pm 140$ & $1082 \mathrm{~b} \pm 80$ & $1065 \mathrm{~b} \pm 95$ \\
\hline BH & 837 & - & - \\
\hline PVS & - & 2900 & - \\
\hline PVH & - & - & 1030 \\
\hline \multicolumn{1}{r|}{ Total DMI (g/h/day ) } & $2010 \pm 85$ & $196 \pm 130$ & $2050 \pm 165$ \\
\hline Water consumption (Ml/h/day) & $1875 \mathrm{~b} \pm 90$ & $171 \mathrm{~b} \pm 165$ & $2205 \mathrm{a} \pm 220$ \\
\hline Feed cost/h/perio (LE ) & $289.44 \mathrm{a} \pm 9$ & $169 \mathrm{~b} \pm 7.0$ & $153 \mathrm{~b} \pm 11.0$ \\
\hline
\end{tabular}

$a$ and $b$ means in the same row superscripted by different letters significantly $(P<0.05)$ differ.

\section{4- Digestion coefficients and nutritive values:}

Data of TDN and DCP are presented in Table (5). All nutrient digestibility and nutritive values were significantly $(P<0.05)$ affected by the tested diets. Generally, the PB-PH showed significantly the highest digestibility coefficient of $\mathrm{OM}$ and $\mathrm{CF}$ than those of PB-PS and the control groups. Whereas PB-PH recorded significantly lowest CP, EE and NFE digestibility values than the control and PB-PS groups. The results are in agreement with Schmeider and Flatt (1975) and Azim et al. (1983). The CP, EE and NFE digestibility values of PB-PH were significantly $(P<0.05)$ lower than the other tested diets. The values of DCP were $10.1,9.6$ and $8.29 \%$ for the control, PB-PS and PB-PH groups, respectively. These are in agreement with Parfitt et al. (1982). Whereas OM and CF of the same group were lower than PB-PS and the control groups, these results are in agreement with Abd El-Baki et al. (1997). The TDN of PB-PH was significantly $(P<0.05)$ lower than the other tested groups, the values were $68.3,66.4$ and $61.2 \%$ for control, potatoes silage and potatoes hay, respectively, this is in agreement with that reported by Azim et al. (1984). Metabolizable energy values was higher in silage compared with control and PB-PH, the values were 3244, 3081 and $2986 \mathrm{kcal} / \mathrm{kg}$ for, potatoes by-products silage, control group and potatoes by- products hay, respectively in agreement with Fekete (1987).

\section{5- Milk production and composition:}

Milk yield and constituents of the experimental groups are shown in Table (6). Milk yield (M), fat, total protein (TP), total solid (TS), and solid not fat (SNF) of PB-PS group significantly increased $(P<0.05)$ than PB-PH group. These improvements in PB-PS group of milk yield and composition were correlated with the high OM , CP and NFE and lower CF and ash than PB-PH. (Table 1) and digestibility of CP, EE and NFE as well as TDN and DP (Table 5). These improvements were correlated too with low level of solanine in the silage form (Table 2). 
Table (5): Digestion coefficients and nutritive values of potato byproducts in form silage and hay.

\begin{tabular}{|c|c|c|c|}
\hline Items & Control & PB-PS & PB-PH \\
\hline Digestion coefficients, \% & \multicolumn{3}{|l|}{} \\
\hline OM & $70.5 \mathrm{~b} \pm 5.3$ & $68.7 \mathrm{~b} \pm 3.8$ & $74.2 \mathrm{a} \pm 6.1$ \\
\hline CP & $71.6 \mathrm{a} \pm 4.9$ & $67.2 \mathrm{~b} \pm 2.7$ & $61.6 \mathrm{c} \pm 3.8$ \\
\hline CF & $54.9 \mathrm{c} \pm 3.2$ & $64.4 \mathrm{~b} \pm 2.9$ & $68.1 \mathrm{a} \pm 1.6$ \\
\hline EE & $66.4 \mathrm{a} \pm 3.1$ & $63.2 \mathrm{a} \pm 2.2$ & $59.5 \mathrm{~b} \pm 3.6$ \\
\hline NFE & $70.2 \mathrm{a} \pm 3.8$ & $72.5 \mathrm{a} \pm 2.5$ & $62.8 \mathrm{~b} \pm 1.8$ \\
\hline Nutritive value, \% & \multicolumn{4}{|l}{} \\
\hline TDN & $68.3 \mathrm{a} \pm 1.10$ & $66.4 \mathrm{a} \pm 0.9$ & $61.20 \mathrm{~b} \pm 1.1$ \\
\hline DCP & $10.1 \mathrm{a} \pm 0.07$ & $9.6 \mathrm{a} \pm 0.1$ & $8.29 \mathrm{~b} \pm 0.3$ \\
\hline ME kcal/kg diet & $3081 \mathrm{a} \pm 65.0$ & $3244 \mathrm{a} \pm 42.0$ & $2986 \mathrm{~b} \pm 34.0$ \\
\hline
\end{tabular}

$a, b$ and $c$ means in the same row superscripted by different letters significantly $(P<0.05)$ differ.

Table (6): Effect of solanine on milk yield and composition of lactating ewe.

\begin{tabular}{|l|c|c|c|}
\hline \multicolumn{1}{|c|}{ Items } & Control & PB-PS & PB-PH \\
\hline Milk yield $(\mathrm{g} / \mathrm{h} / \mathrm{d})$ & $672 \mathrm{a} \pm 34.0$ & $649 \mathrm{~b} \pm 51.0$ & $587 \mathrm{~b} \pm 29.0$ \\
\hline $4 \%$ fat corrected milk(g/h/d ) & $1038.9 \mathrm{a} \pm 28.0$ & $979.1 \mathrm{~b} \pm 42.0$ & $842.4 \mathrm{~b} \pm 19.0$ \\
\hline Total solids $(\mathrm{g} / \mathrm{h} / \mathrm{d})$ & $146.0 \mathrm{a} \pm 13.4$ & $131.8 \mathrm{~b} \pm 9.86$ & $108.0 \mathrm{c} \pm 4.77$ \\
\hline Fat $\mathrm{g} / \mathrm{h} / \mathrm{d})$ & $54.4 \mathrm{a} \pm 0.90$ & $50.9 \mathrm{a} \pm 1.12$ & $40.4 \mathrm{~b} \pm 0.57$ \\
\hline Solid not fat $(\mathrm{g} / \mathrm{h} / \mathrm{d})$ & $91.5 \mathrm{a} \pm 2.45$ & $89.1 \mathrm{a} \pm 4.52$ & $81.1 \mathrm{~b} \pm 2.87$ \\
\hline Total protein $(\mathrm{g} / \mathrm{h} / \mathrm{d})$ & $53.4 \mathrm{a} \pm 1.98$ & $49.5 \mathrm{a} \pm 3.47$ & $44.7 \mathrm{~b} \pm 2.66$ \\
\hline \multicolumn{5}{|l}{} \\
\hline Milk composition \% & $21.24 \mathrm{a} \pm 0.4$ & $20.69 \mathrm{a} \pm 0.1$ & $19.00 \mathrm{~b} \pm 0.2$ \\
\hline Total solid & $7.64 \mathrm{a} \pm 0.2$ & $7.39 \mathrm{a} \pm 0.1$ & $6.90 \mathrm{~b} \pm 0.2$ \\
\hline Fat & $13.6 \mathrm{a} \pm 0.3$ & $13.30 \mathrm{a} \pm 0.1$ & $12.10 \mathrm{~b} \pm 0.3$ \\
\hline Solid not fat & $7.9 \mathrm{a} \pm 0.1$ & $7.60 \mathrm{a} \pm 0.1$ & $6.40 \mathrm{~b} \pm 0.2$ \\
\hline Total protein & $5.02 \mathrm{a} \pm 0.2$ & $4.80 \mathrm{a} \pm 0.2$ & $4.17 \mathrm{~b} \pm 0.1$ \\
\hline Lactose
\end{tabular}

$a-b$ means in the same row superscripted by different letters significantly $(P<0.05)$ differ.

\section{6 - Blood picture:}

Data of blood analysis in Table (7) indicated that solanine have an enhancement effect on white blood cells which is in agreement with that reported by Pollman and Danielson (1980). The PB-PH (high solanine) increased haematocrit, AST, ALT, urea, creatinine and bilirubin than the other groups, while the other tested components were decreased in the same treatments. 
Saleh, M.R.M.

Table (7): Blood picture of ewes as affected by potato by-products as silage or hay.

\begin{tabular}{|l|c|c|c|}
\hline \multicolumn{1}{|c|}{ Items } & Control & PB-PS & PB-PH \\
\hline R.B.C. $\left(10^{6} / \mu \mathrm{l}\right)$ & $10.20 \mathrm{a} \pm 0.10$ & $9.80 \mathrm{~b} \pm 0.07$ & $9.10 \mathrm{~b} \pm 1.30$ \\
\hline W.B.C. $\left(10^{3} / \mu \mathrm{l}\right)$ & $7.20 \mathrm{~b} \pm 0.12$ & $7.30 \mathrm{~b} \pm 0.13$ & $9.24 \mathrm{a} \pm 0.15$ \\
\hline Hemoglobin $(\mathrm{g} / \mathrm{dl})$ & $10.30 \mathrm{a} \pm 0.11$ & $9.70 \mathrm{a} \pm 0.01$ & $7.83 \mathrm{~b} \pm 0.08$ \\
\hline Hematocrit $(\%)$ & $21.50 \mathrm{c} \pm 0.80$ & $25.50 \mathrm{~b} \pm 0.80$ & $33.20 \mathrm{a} \pm .0 .00$ \\
\hline Total protein $(\mathrm{g} / 100 \mathrm{~g})$ & $8.60 \mathrm{a} \pm 0.06$ & $8.30 \mathrm{a} \pm 0.04$ & $6.77 \mathrm{~b} \pm 0.08$ \\
\hline Globulin $(\mathrm{g} / 100 \mathrm{~g})$ & $3.86 \mathrm{a} \pm 0.03$ & $3.92 \mathrm{a} \pm 0.05$ & $3.74 \mathrm{~b} \pm 0.02$ \\
\hline Albumen $(\mathrm{g} / 100 \mathrm{~g})$ & $4.74 \mathrm{a} \pm 0.01$ & $4.38 \mathrm{a} \pm 0.03$ & $3.03 \mathrm{~b} \pm 0.05$ \\
\hline AST $(\mu / \mathrm{ml})$ & $44.0 \mathrm{~b} \pm 0.30$ & $38.00 \mathrm{c} \pm 3.70$ & $76.00 \mathrm{a} \pm 5.60$ \\
\hline ALT $(\mu / \mathrm{ml})$ & $27.0 \mathrm{~b} \pm 2.10$ & $20.00 \mathrm{c} \pm 1.10$ & $40.00 \mathrm{a} \pm 0.80$ \\
\hline Total cholesterol $(\mathrm{mg} / 100 \mathrm{ml})$ & $144 \mathrm{a} \pm 4.60$ & $128.0 \mathrm{~b} \pm 5.70$ & $109.0 \mathrm{c} \pm 7.20$ \\
\hline Urea $(\mathrm{mg} / 100 \mathrm{ml})$ & $18.30 \mathrm{~b} \pm 1.80$ & $21.90 \mathrm{~b} \pm 1.30$ & $33.60 \mathrm{a} \pm 2.10$ \\
\hline Creatininem $(\mathrm{mg} / 100 \mathrm{ml})$ & $0.80 \mathrm{~b} \pm 0.10$ & $0.74 \mathrm{~b} \pm 0.20$ & $1.30 \mathrm{a} \pm 0.14$ \\
\hline Bilirubin $(\mathrm{mg} / 100 \mathrm{ml})$ & $0.40 \mathrm{~b} \pm 0.02$ & $0.39 \mathrm{~b} \pm 0.03$ & $0.60 \mathrm{a} \pm 0.08$ \\
\hline
\end{tabular}

a, b and $c$ means in the same row superscripted by different letters significantly $(P<0.05)$ differ.

\section{7- Groth performance of lambs:}

The new born lambs which suckled their mother's milk showed significant $(P<0.05)$ differences in the body weight gain when ewes fed on the potato hay. This group recorded the lowest values compared with the group which fed on potato silage and the control one, the values of daily weight gain $(\mathrm{g})$ were $159.81,145.62$ and 108.65 for control, potatoes silage and potatoes hay groups, respectively (Table 8 ). This decrease in the daily weight gain of the group fed on PB-PH may be due to the lower milk yield and its contents from total protein, fat and total solids. The results indicated that solanine have an enhancement effect on the humoralimmune response, which is in agreement with that reported by Polman and Danielson (1980).

Table (8): Growth performance of lambs as affected by the tested rations.

\begin{tabular}{|l|c|c|c|}
\hline \multicolumn{1}{|c|}{ Items } & Control & PB-PS & PB-PH \\
\hline No. of animals & 6 & 6 & 6 \\
\hline Initial weight $(\mathrm{kg})$ & $3.56 \mathrm{a} \pm 0.12$ & $3.42 \mathrm{a} \pm 0.14$ & $3.62 \mathrm{a} \pm 0.09$ \\
\hline Weaning weight $(\mathrm{kg})$ & $18.24 \mathrm{a} \pm 0.43$ & $17.03 \mathrm{a} \pm 0.51$ & $13.98 \mathrm{~b} \pm 0.74$ \\
\hline Total body gain $(\mathrm{kg})$. & $14.7 \mathrm{a} \pm 0.60$ & $13.6 \mathrm{a} \pm 0.50$ & $10.4 \mathrm{~b} \pm 0.40$ \\
\hline Daily gain $(\mathrm{g})$ & $159.8 \mathrm{a} \pm 0.25$ & $145.6 \mathrm{a} \pm 0.20$ & $108.7 \mathrm{~b} \pm 0.10$ \\
\hline Milk consumption $(\mathrm{g} / \mathrm{h} / \mathrm{d})$ & $672 \mathrm{a} \pm 27.0$ & $639 \mathrm{a} \pm 43.0$ & $547 \mathrm{~b} \pm 25.0$ \\
\hline Milk as DMl $(\mathrm{g} / \mathrm{h} / \mathrm{d})$ & $146.0 \mathrm{a} \pm 3.48$ & $129.8 \mathrm{a} \pm 4.50$ & $101.1 \mathrm{~b} \pm 3.80$ \\
\hline Feed conversion & $4.8 \mathrm{~b} \pm 0.06$ & $4.9 \mathrm{a} \pm 0.02$ & $5.5 \mathrm{a} \pm 0.03$ \\
\hline Protein consumption $(\mathrm{g} / \mathrm{h} / \mathrm{d})$ & $53.4 \mathrm{a} \pm 3.20$ & $48.8 \mathrm{~b} \pm 2.70$ & $37.9 \mathrm{c} \pm 1.20$ \\
\hline
\end{tabular}

a, $b$ and $c$ means in the same row superscripted by different letters significantly $(P<0.05)$ differ.

8- Economical efficiency:

This study cleared that use of potato by-products in ruminant feeding up to $50 \%$ of their requirements, it decreased feed costs by 33.05 and 
$28.41 \%$ for potato silage and potato hay, respectively compared with control group. These decreases in cost back to that potato by-products as silage or hay are cheap by products. These data are in agreement with Murdoch (1962).

\section{CONCLUSION}

From this study, it could be concluded that potato by-products can be used in ruminant feeding, particularly in form of silage.

\section{REFERENCES}

Abd El-Baki, S.M; Zaki A.A.; Bassuny, S.M. and El-Gendy, K.M. (1997). Nutritional studies on some green forages in Egypt. J. Nutr. Feeds, 1 (special Issue): 133 - 143.

Abdelhamid, A.M., M.S. Nowar, S.M. Bassuny and G.I. El- Emam (2001). Evaluation of unconventional silage making using plant and animal wastes in feeding ruminants. J. Agric. S Cl. Mansoura Univ., 26: 5349 -5360 .

Abou Akkada, A.R. (1984). Evaluation of present status and potential development of animal feed resources in the Arab countries AC Khartom, $129 \mathrm{p}$.

Abou Akkada, A.R. and Nour, A.M. (1986). Ensilage and improvement of feeding value. Alexandria, September, $40 \mathrm{p}$.

Alozie, S.O., Sharma, R.P. and Salunkhe, D.K. (1978). Inhibition of rat cholinesterase isoenzymes in vitro and in vivo by the potatoglycoalkaloid, ( alpha-solanine and alpha caconine). J. Food Biochem., 2: 259 - 276.

Anon. (1984). Solanine food poisoning associated with a school lunch. J. Agric . Food Chem., 483 - 490.

A.O.A.C. (2000). Association of Official Analytical Chemists of Official Methods of Analysis17 ed. Washington D.C.

Azim, A., Shaikh, H.A. and Ahmed, R. (1983). Toxic effects of high glycoalkaloid feeding on the protein digestibility and growth of the rabbits. J. Pharm. Univ. Karachi., 2: 15-24.

Azim, A., Shaikh, H.A. and Ahmed, R. (1984). Toxic effects of high glycoalkaloid feeding on the red blood cell counts and haemoglobin concentration of rabbit blood. J. Pharm. Univ. Karachi, 3: 43 - 49.

Bartiles, H.(1971).Calorimetric determination of creatinine. Clin.Acta.32 - 81.

Bushway, R.J. and Ponnampalam, R. (1985). alpha-solanine content of potato products . J. Agric. Food Chem., 34: 277 - 279.

Carman, A.S.; Kuan, S.S. and Francis , O.J. (1984). Determination of the potato glycoalkaloids J. Agric. Food Chem., $66: 582-586$.

Chaube, S. and Swinyard, C.A. (1976). Teratological and toxicologicalstudies of alkaloidal and phenolic compounds from Solanum tuberosum L .Toxicol . Appl . Pharmacol., 36 : 227- 237.

Dalvi, R.R. and Bowie, W.C. (1983). Toxicology of solanine: an overview. Vet. Hum. Toxicol., 25: 13-15.

Doumas, B.T., Watson, W. and Biggs, H.G. ( 1971). A method determination of plasma albumin. Clin . Chemists Acya, 31:87. 
Duncan, D.B.(1955). Maltiple range and multiple F-test . Biometrics,11: 1-42

Elveback , L.R. (1970). J. AM. Med. Ass., 211: 69

Fakete, S. (1987). The new Hungarian system for the evaluation of feed energy . proceeding. 1st North. American congress - Oct . $10-13$, Por Hand - OR- U. S. A.

Gaines, S.M. (1963). Relation between percentage of fat content and yeild of milk. 1- correction of Milk yeild for fat content. Agric Handbook 379, USDA . Washington . D.C.

Gull, S.D.; Isenberg, F.M. and Bryan, H.H. (1970). Alkaloid toxicology of Solanum-tuberosum. Hort. Science, 5: 316.

Hansen, A.A. (1925). Two fatal cases of potato poisoning. Science, 61: 340 341.

Jadhav, S.J., Sharma, R.P. and Salunkhe, D.K . (1981). Naturally occurring toxic alkaloids in foods. Crit. Rev. Toxicol., $9: 21-104$.

Ling, E.R. (1963). Text Book of Dairy Chemistry, Vol.11. Practical Champ man and Hill , London . 3 rd Ed.

Linne, J.J. and Ringsrud, K.M. (1992). Basic Techniques in clinical Laboratory Science . 3멍. Ed., Mosby year book.

Miller, S.E. and Weller, J.M. (1971). Textbook of Clinical Pathology. 8th Ed. The Williams and Wikins Co., Baltimore Scientific Book. Agency. Calcutta.

Monnet, L. (1963). Determination uf bilirubin Animal Biol. Clin ., 21: 717.

Morris, S.C. and Lee, T.H. (1984). The toxicity and teratogenicity mutagens. Mutat. Res., 89: 95 - 136.

Murdoch, J. (1962). Making and feeding silage. Farming Press Books, LTD, London.

N.R.C. National Research Council (1990). Nutrient Requirements of Sheep National and Academy Press, $17^{\text {th }}$ Edition.

Parfitt, D.E.; Peloquin, S.J. and Jorgensen, N. A. (1982). The nutritional value of pressed potato vine silage American Potato, Journal, 59: 415 $-423$.

Patil, B.C., Sharma, R.P., Salunke, D.K and Salunkhe, K. (1972). Evaluation of solanine toxicity. Food Cosmet. Toxicol., 10: 395 - 398.

Patton, C.J. and Crouch, B.C. (1977). Spectrophotometeric and kinetics investigation of the berthelot reaction for the determination of ammonia. Anal. Chem., 49: 464 - 469.

Polman, D.S. and Danielson, D.M. (1980). Enhancement effect to the humoralimmune response on blood cells. Potato Journal,59:415 - 423.

Renwick, J.H., Claringbold, W.D.B., Earthy, M.E., Few, J.D. and Mclean, A.C.S. (1984). Neural-tube defects produced in Syrian hamsters by potato glycoalkaloids. Teratology, 30: 371 - 381 .

Reitman, S. and Frankle, S. (1957). Amethod for determination of plasma GOT and GPT. Am. J. Clin. Path., 28: 108.

SAS (1996). SAS/STAT Guide for Personal Computer . SAS inst. Cary, N.C.

Schmeider, B. H. and Flatt, W.P. (1975). The Evaluation of Feeds throw the Digestibility Experiment. The University of Georgia Press, Athens, 415 p. 
Sultan , B.E. (1995). Studies on the effects of introducing chemically treated roughages in the feeds of farm livestock. M.Sc. Thesis, Fac. of Agric., Mansoura Univ.

Swinyard, C.A. and Chaube, S. (1973). Are potatoes teratogenic for experimental animals? Teratology, 8: 349-357.

Van Keulen, J. and Young, B.A. (1977). Evaluation of acid insoluble ash as natural marker in ruminant digestibility studies. Anim. Sci., 44: 2 .

Weichselbaum,M.H. (1989). Colorimetric determination of total protein. Anim. J. PATH., 16: 40.

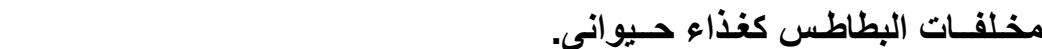

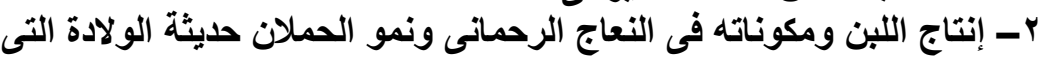

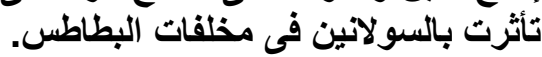

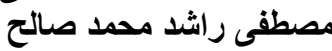

$$
\begin{aligned}
& \text { معهُ بحوث الإنتاج الحيوانى ـ مركز البحوث الزراعية ـ دقى ـ مصر. }
\end{aligned}
$$

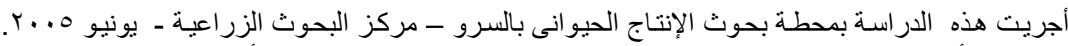

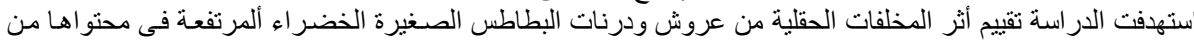

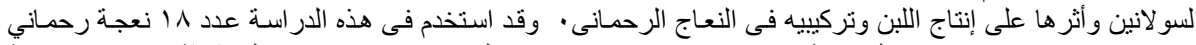

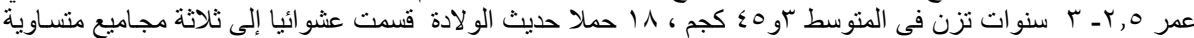

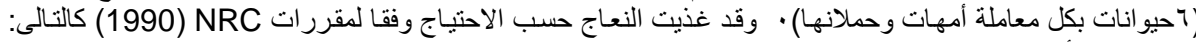

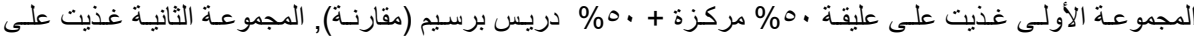

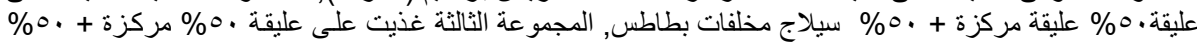

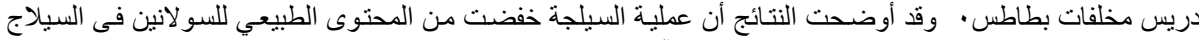

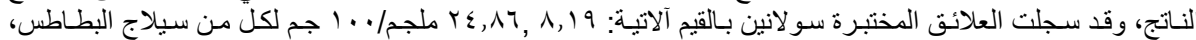

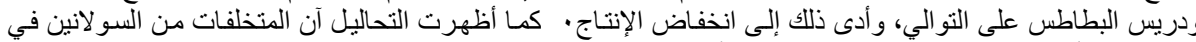

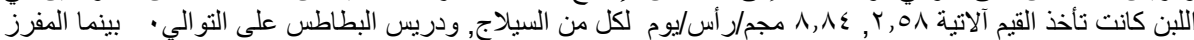

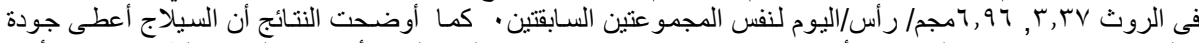

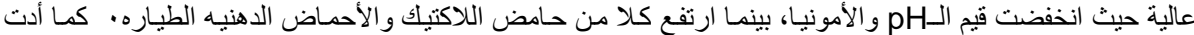

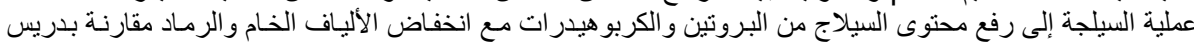

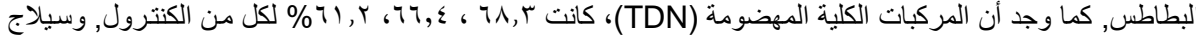

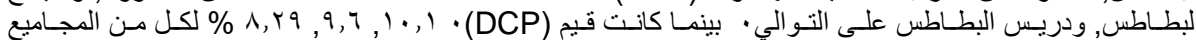

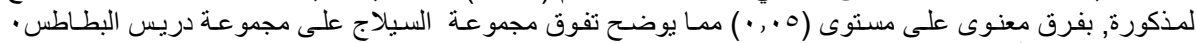

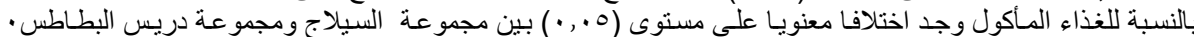

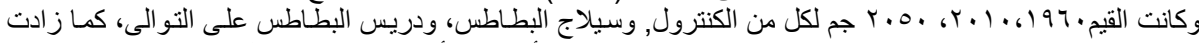

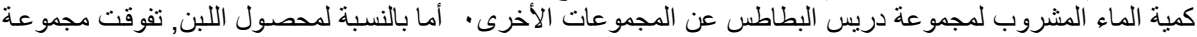

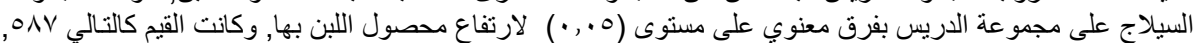

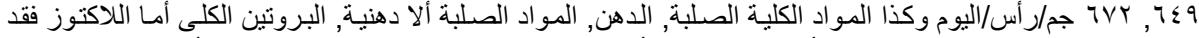

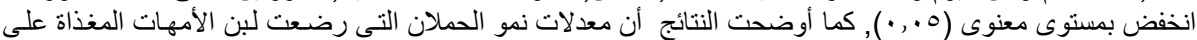

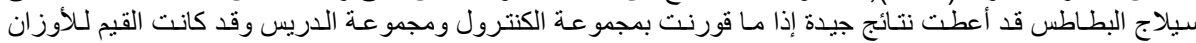

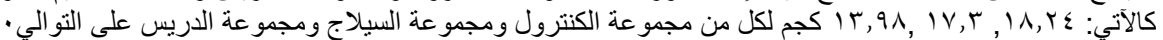

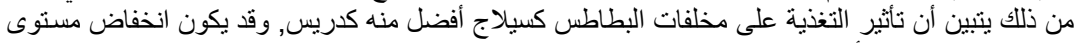

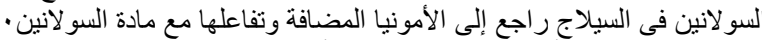

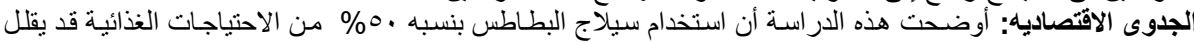

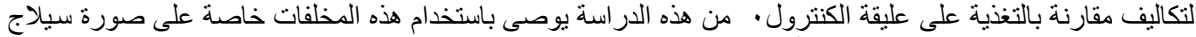

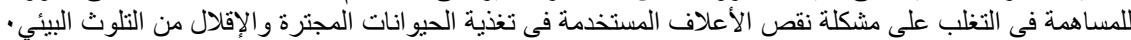

